\title{
OPERASI EKONOMIS DAN UNIT COMMITMENT PEMBANGKIT THERMAL PADA SISTEM KELISTRIKAN JAMBI
}

\author{
Delima*, Syafii \\ Jurusan Teknik Elektro, Fakultas Teknik, Universitas Andalas \\ *Corresponding author, e-mail : delimarara@gmail.com
}

\begin{abstract}
Abstrak-Operasi ekonomis pada pembangkit tenaga listrik merupakan suatu aspek penting dalam manajemen sistem tenaga listrik khusus nya operasi ekonomis, dalam makalah ini membahas tentang operasi ekonomis dan unit Commitment untuk koordinasi pembangkit sistem kelistrikan Jambi dengan menerapkan metode daftar prioritas. Data yang digunakan dalam makalah ini adalah pembangkit listrik tenaga termal pada bulan November 2015 dilakukan di Provinsi Jambi diperoleh hasil kurang ekonomis, untuk itu perlu adanya perhitungan pada operasi ekonomis untuk unit-unit pembangkit. Kombinasi yang dipilih adalah kombinasi yang menghasilkan biaya bahan bakar yang paling minimum. Pada pembebanan daya 235 MW dengan mengoperasikan 4 unit pembangkit yaitu PLTG Batanghari unit 1, PLTMG segai gelam unit 3, PLTG Sewa unit 6, PLTG Batanghari unit 2. Dengan biaya operasi sebesar Rp.102.864.238,65. Metode daftar prioritas dalam menyelesaikan permasalahan unit commitment memberikan hasil yang lebih yang lebih optimal dibandingkan dengan total biaya yang dikeluarkan oleh PT.PLN (Persero) Wilayah Jambi. Total biaya pembangkit dari PT.PLN (Persero) Wilayah Jambi Sebesar Rp. 163.755.996,30 dengan demikian ada penghematan sebesar Rp. 60.891.757,65./bulan. Dari hasil pengolah data ini maka operasi ekonomis pada pembangkit tenaga listrik di Provinsi Jambi perlu dikaji ulang agar lebih efesien dalam penggunaan energi listrik.
\end{abstract}

Kata Kunci : Optimalisasi penjadwalan pembangkit, Operasi ekonomis, Kombinasi on/off daftar prioritas.

\begin{abstract}
Abstrak-Economical operation at power plants is an important aspect in the management of power system economic operation, his specialty in this paper discusses economic and operating unit Commitment to coordination of power plant electrical systems Jambi by applying method of the list of priorities. The data used in this paper is thermal power plant in November 2015 conducted in Jambi province retrieved results less economical, for it is need for calculation of economical operations for power generation units. The selected combination is the combination that produces the most fuel costs to a minimum. On the imposition of $235 \mathrm{MW}$ power by operating unit 4 generating namely PLTG Batanghari unit 1, PLTMG segai gelam unit 3, unit 6, Rent PLTG PLTG Batanghari unit 2. With operating expenses amounted to Rp.,65.102.864.238 method of the list of priorities in solving unit commitment gives results which are more optimal as compared to the total costs incurred by PT. PLN (Persero) Area Of Jambi. The total cost of the plant from PT. PLN (Persero) Rp Jambi Region. 163,755,996.30 thus there are savings of Rp. 60,891,757.65. per mounth From the results of this data processing operations are economical in power plants in Jambi province need to be rethought to make it more efficient in the use of electrical energy.
\end{abstract}

Keywords : Optimization of plant scheduling, economical operation, Combination of on / off priority list.

Copyright (C) 2016 JNTE. All rights reserved

\section{PENDAHULUAN}

Suatu sistem pembangkit secara garis besar terdiri dari pembangkit listrik tenaga hidro dan pembangkit listrik tenaga termal. Kedua pusat listrik tersebut terinterkoneksi untuk melayani kebutuhan beban, Pembangkit listrik tenaga termal menggunakan sumber energi yang tidak dapat diperbaharui. Karena itu memerlukan pengoperasian yang optimal agar tidak ada energi yang terbuang percuma.
Pada pembangkit dan penyaluran daya listrik ini selalu dilakukan pembangian pembeban pada unit pembangkit yang akan mensuplai beban[1]. Pertimbangan yang diambil untuk mencapai operasi ekonomis pada sistem tenaga, terdapat dua pokok permasalahan yang harus dipecahkan dalam operasi ekonomis pembangkit pada sistem tenaga listrik yaitu : pengaturan unit pembangkit (unit commitment) dan penjadwalan ekonomis (economic dispatch). 
Unit commitment bertujuan untuk menentukan jadwal (schedule) on/off unit pembangkit yang paling optimun dioperasikan dalam memenuhi beban yang diperkirakan untuk mencapai biaya bahan bakar minimum rupiah [2].

\section{LANDASAN TEORI}

\subsection{Pertimbangan Operasi Ekonomis}

Operasi ekonomis ialah proses pembagian beban total kepada masing-masing unit pembangkit, seluruh unit pembangkit dikontrol terus menerus dalam interval waktu tertentu sehingga dicapai pengoperasian yang optimal, dengan demikian pembangkit tenaga listrik dapat dilakukan dengan cara paling ekonomis.

Pertimbangan yang diambil untuk mencapai operasi ekonomis pada sistem tenaga dapat dibagi atas dua bagian, yaitu :

1. Economic Dispatch yaitu pengaturan sistem pembangkit yang berkomitmen dalam melayani beban untuk meminimalisasi rugirugi saluran dan total biaya produksi.

2. Unit commitment yaitu menentukan jadwal (schedule) on/off pembangkit untuk dapat memenuhi kebutuhan beban.

\subsection{Optimasi unit pembangkit thermal}

Yang dimaksud dengan operasi ekonomis pembangkit thermal ialah proses pembagian atau penjadwalan beban total dari suatu sistem kepada masing-masing pusat pembangkitnya, sedemikian rupa sehingga jumlah biaya pengoperasian adalah seminimal mungkin. Seluruh pusat-pusat pembangkit dalam suatu sistem dikontrol terus menerus sehingga pembangkitan tenaga dilakukan dengan cara paling ekonomis.

\subsection{Karakteristik Input-Output Pembangkit}

Untuk menganalisis permasalahan mengenai operasi dalam sistem tenaga, khususnya masalah operasi ekonomis, diperlukan dasar tentang karakteristik inputouput dari suatu unit pembangkit thermal. Karakteristik input output pembangkit thermal adalah karakteristik yang menggambarkan hubungan antara input bahan bakar (liter/jam) dan output yang dihasilkan oleh pembangkit (MW). Untuk menggambarkan karakteristik input output dapat dilihat pada Gambar 1, yang menunjukkan karakteristik input-output suatu unit pembangkit tenaga uap yang ideal. Input unit yang ditunjukkan pada sumbu ordinat adalah kebutuhan energi panas (MBtu/jam) atau biaya total per jam (R/jam). Outputnya adalah output daya listrik dari unit tersebut. Untuk masalah operasi ekonomis, biasanya kurva karakteristik input output pembangkit didekati dengan persamaan polynomial tingkat dua (kuadrat) persamaannya :

$$
H_{i}=a_{i}+\beta_{i} P T_{i}+\gamma P T^{2}{ }_{i}
$$

Dimana :

$H$ = Input Pemakaian bahan bakar(Liter/Jam)

$P \quad=$ Daya listrik yang dibangkitkan(MW)

$\alpha, \beta, \gamma=$ Konstanta-konstanta

\subsection{Economic Dispatch}

Kenaikan biaya produksi (Inceremental production Cost) didefinisikan sebagai perubahan biaya bahan bakar yang terjadi bila terjadi perubahan daya listrik yang dibangkitkan. Perubahan jumlah bahan bakar yang terjadi karena perubahan keluaran, didefinisikan sebagai IFR

(Incremantal Fuel Rate), Persamaan matematisya adalah :

$$
\text { Incremental fual }(\mathrm{IFR})=\frac{\Delta F}{\Delta P}
$$

Incremantal Fuel Rate ini jug dapat dinyatakan dengan kurva yang disebut kurva laju kenaikan biaya bahan bakar atau Incremantal Fuel Cost (IFC) dengan cara mengalikan IFR dengan biaya bahan bakarnya.

$$
\text { IFC = IFR X Fuel Cost } \frac{\text { rupiah }}{M W h}
$$

Konfigurasi yang akan dipelajari dalam bagian ini. Sistem ini terdiri dari $\mathrm{N}$ termal-unit pembangkit yang terhubung ke satu bus-bar yang menyajikan menerima beban listrik $\mathrm{P}_{\text {load}}$. Input ke setiap unit, ditampilkan sebagai 4, mewakili tingkat biaya unit. Output dari setiap unit, adalah daya listrik yang dihasilkan oleh unit tertentu. Tingkat total biaya sistem ini, tentu saja jumlah dari biaya dari masing-masing unit individu. Kendala penting pada operasi dari sistem ini adalah bahwa jumlah kekuatan keluaran harus sama dengan permintaan beban.

Matematis berbicara, masalah dapat dinyatakan sangat ringkas. Artinya fungsi tujuan 
$F_{T}$, adalah sama dengan biaya total untuk memasok beban ditunjukkan. Masalahnya adalah untuk meminimalkan $F_{T}$, pada kendala bahwa jumlah kekuatan yang dihasilkan harus sama dengan beban yang diterima. Perhatikan bahwa kerugian transmisi diabaikan dan batasan operasi tidak secara eksplisit dinyatakan ketika merumuskan masalah ini, Itu adalah:

$$
\begin{aligned}
F_{T} & =F_{1}+F_{2}+F_{3}+\ldots+F_{N} \\
& =\sum_{i=1}^{N} F i(P i) \\
\phi=0 & =P_{\text {load }}-\sum_{i=1}^{N} P i
\end{aligned}
$$

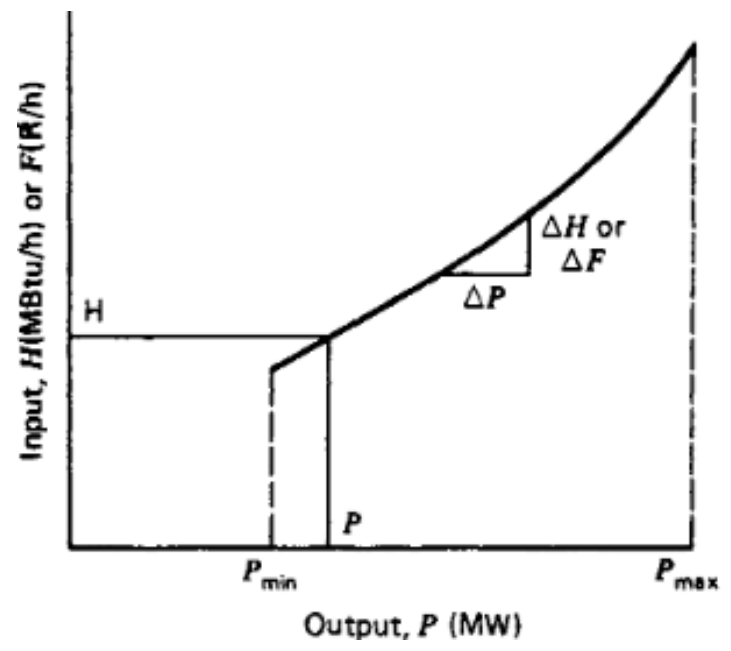

Gambar 1. Karakteristik Masukan - Keluaran

\subsection{Unit Commitment}

Unit Commitment Penjadwalan pembangkit (Unit Commitment) ini menentukan mana unit pembangkit yang commit (on) dan unit mana yang (off) dalam melayani beban sistem selama periode waktu tertentu dengan memperhatikan kondisi optimal ekonomi dan memenuhi batasan-batasan teknis dalam pengoperasian pembangkit di dalam sistem tenaga.

Kombinasi unit pembangkit merupakan kombinasi on/off dari beberapa unit yang ada dalam sistem. Dari n buah unit pembangkit, jumlah kombinasi on/off nya $2^{\mathrm{n}}-1$ buah,dari kombinasi on/off unit pembangkit akan dipilih kombinasi mana yang akan dijadualkan. Evalusi pemilihan dilakukan dengan menghitung biaya optimum (economic dispatch) untuk setiap kombinasi- kombinasi on/off unit pembangkit pada beban tertentu.

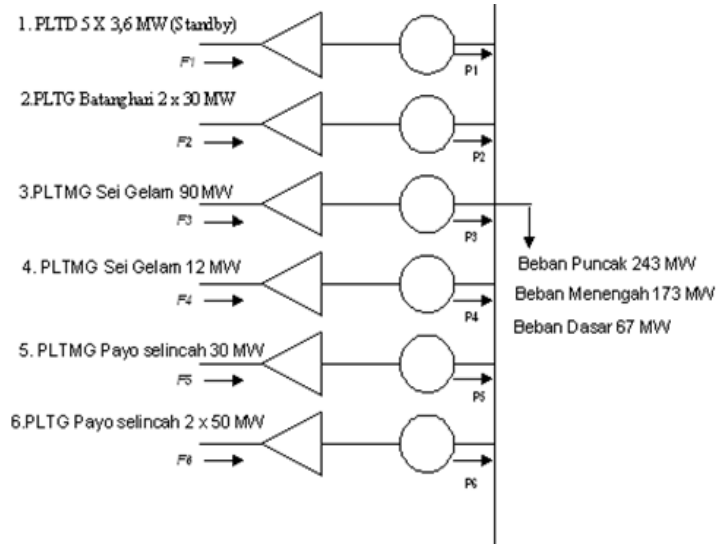

Gambar 2. Unit Pembangkit Sistem Kelistrikan Jambi

\subsection{Metode Daftar Prioritas}

Metode daftar prioritas merupakan suatu metode penyelesaian Unit commitment yang paling sederhana. Pada motede ini kombinasi on/off pembangkitan didasarkan pada urutan prioritas. Untuk menentukan urutan prioritas diperoleh dari biaya produksi rata - rata persatuan output yang didasarkan pada beban penuh (Pmax) dari tiap unit, dan urutkan berdasarkan nilai biaya produksi tersebut. Unit yang dioperasikan pertama adalah unit yang memiliki biaya produksi terendah dan paling akhir adalah unit yang memiliki biaya produksi termahal. Algoritma unit commitment dengan daftar prioritas.

Pada metode daftar ini kombinasi on-off unit pembangkit didasarkan pada urutan prioritas. Untuk menentukan urutan prioritas diperoleh dari biaya produksi rata-rata persatuan output yang didasarkan pada Pmax.

\section{METODOLOGI PENELITIAN}

\subsection{Sistem Tenaga Listrik di Jambi}

Sistem kelistrikan sektor pembangkit Jambi melayani pelanggan PT.PLN yang ada Kota dan kabupaten Jambi. Dimana saat ini kapasitas daya terpasamg mesin pembangkit yang dimiliki oleh PT. PLN (Persero) Wilayah Jambi sebesar 355 MW dengan daya mampu mesin pembangkit sebesar $322 \mathrm{MW}$ dan beban tertinggi sebesar 176 MW. Ada beberapa unit pembangkit milik PT. PLN yang telah berumur (efesien lebih rendah), sehingga PT.PLN (Persero) Wilayah Jambi bekerja sama dengan pembangkit-pengbangkit swasta untuk melakukan jual beli energi listrik 
sehingga diharapkan dapat memenuhi daya terpasang yang dibutuhkan.

Pembangkit-pembangkit yang dikelolah oleh PT.PLN (Persero) Wilayah Jambi yaitu :

1. Sektor Jambi : Pembangkit Listrik Tenaga Diesel (PLTD) Payo selincah 6 unit generator dan Pembangkit Listrik Tenaga Gas (PLTG) Batanghari 2 unit dan Pembangkit Listrik Tenaga Mesin Gas (PLTMG) Sei Gelam 1 unit.

2. Pembangkit Sewa : Pembangkit Listrik Mesin Gas Sei Gelam 1 unit dan Pembangkit Listrik Tenaga Mesin Gas P.selincah 1 unit dan pembangkit Listrik Tenaga Gas BOT P.selincah 2 unit.

\subsection{Prosedur Penelitian}

Prosedur penelitian dapat dilihat pada Gambar 3 Flowchart penelitian.

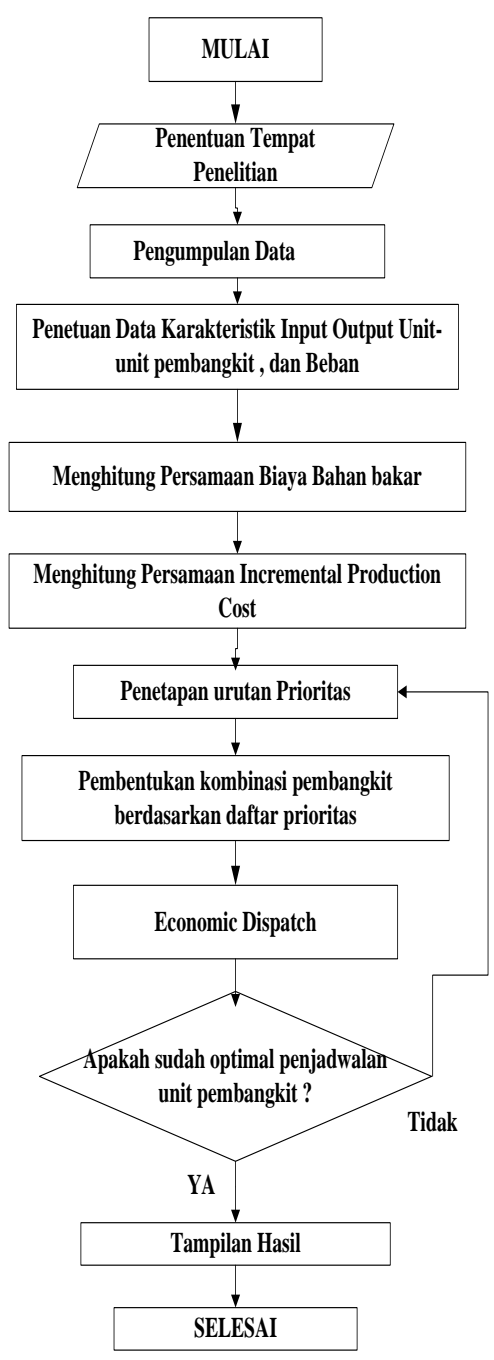

Gambar 3. Flowchart penelitian

\section{HASIL DAN ANALISIS}

\subsection{Data}

Penjadwalan unit pembangkit bertujuan untuk mengoptimalkan pembebanan unit pembangkit yang beroperasi dengan menekan besarnya biaya bahan bakar se-ekonomis mungkin atau yang dikenal dengan istilah operasi ekonomis. Keadaan optimal tersebut didapat apabila pembangkit dioperasikan dengan icnremental cost (laju penambahan biaya) yang sama dengan memperhatikan batas maksimum dan batas minimum pengoperasian unit pembangkit.

Data yang digunakan dalam penelitian ini yaitu data sistem kelistrikan Jambi yang terdiri dari 10 bus dengan 6 pembangkit. Dalam penelitian ini hanya menggunakan pembangkit thermal yaitu:

1. PLTG Batanghari \#1 $30 \mathrm{MW}$

2. PLTG Batanghari \#2 $30 \mathrm{MW}$

3. PLTMG Peaker Sei Gelam $90 \mathrm{MW}$

4. PLTMG sewa Sei Gelam $12 \mathrm{MW}$

5. PLTMG Payo Selincah $30 \mathrm{MW}$

6. PLTG Payo Selincah $100 \mathrm{MW}$

Sedangkan untuk pembangkit lainnya tidak dalam penelitian ini. Adapun data uji yang digunakan yaitu beban harian pembangkit pada hari minggu tanggal 20 Nopember 2015 yang diperoleh dari PT. PLN (Persero) Jambi. Beban harian pembangkit sistem kelistrikan Jambi terdiri dari 24 jam yang kemudian peneliti jadikan 3 periode, dimana Beban harian dapat dilihat pada Tabel 1

Tabel 1. Beban Harian

\begin{tabular}{|c|c|c|}
\hline No & Jam (h) & Beban (MW) \\
\hline 1 & $06.00-17.00$ & 139 \\
2 & $18.00-22.00$ & 235 \\
3 & $23.00-05.00$ & 146 \\
\hline
\end{tabular}

Setiap unit pembangkit memiliki titik head rate yang diperoleh dari data pembangkit, apabila data tersebut didekati dengan fungsi polynomial maka akan diperoleh persamaan laju panas dari pembangkit thermal dalam perkalian persamaan laju panas dengan biaya bahan bakar akan menghasilkan persamaan baru yang menggambarkan karakteristik biaya bahan bakar pembangkit thermal.

Data lain yang dibutuhkan dalam perhitungan operasi ekonomis pembangkit 
thermal yaitu batas pengoperasian pembangkit serta data riil sistem penjadwalan unit pembangkit yang nantinya akan dibandingkan dengan hasil perhitungan peneliti. Batas pengoperasian pembangkit dan data riil sistem penjadwalan unit pembangkit dapat dilihat pada Tabel 2 dan Tabel 3.

Tabel 2. Batas Pengoperasian Pembangkitan Sistem Kelistrikan Jambi

\begin{tabular}{|l|c|c|}
\hline \multicolumn{1}{|c|}{ Unit Pembangkit } & P maks (NW) & P min (NW) \\
\hline Unit 1 PLTG Batanghari \#1 30 MW & 29 & 26 \\
Unit 2 PLTG Batanghar \#2 30 MW & 29 & 26 \\
Unit 3 PLTMG Peaker Sei Gelam 90 MW & 80 & 60 \\
Unit 4 PLTMG seva Sei Gelam 12 MW & 12 & 7 \\
Unit 5 PLTMG Pavo Selincah 30 MW & 30 & 15 \\
Unit 6 PLTG Payo Selincah 100 MW & 100 & 66 \\
\hline
\end{tabular}

Tabel 3. Penjadwalan Unit Pembangkit Sistem Kelistrikan Jambi Sebelum Optimasi (Minggu, 20 November 2015)

\begin{tabular}{|c|c|c|c|c|}
\hline Pembangkit & Dava Mampu & \multicolumn{3}{|c|}{ Waktu (h) } \\
\hline (MW) & $(\mathrm{MW})$ & $06.00-17.00$ & $18.00-22.00$ & $23.00-05.00$ \\
\hline Unit 1 & 29 & 29 & 29 & 29 \\
\hline Unit 2 & 29 & 29 & 29 & 29 \\
\hline Unit 3 & 80 & - & 69 & - \\
\hline Unit 4 & 12 & 12 & 12 & 12 \\
\hline Unit 5 & 30 & 22 & 29 & 22 \\
\hline Unit 6 & 100 & 47 & 67 & 54 \\
\hline \multicolumn{2}{|c|}{ Total } & 139 & 235 & 146 \\
\hline
\end{tabular}

\subsection{Hasil dan pembahasan}

Untuk dapat menghitung operasi ekonomis pembangkit terlebih dahulu dicari fungsi biaya bahan bakar pembangkit thermal sistem kelistrikan Jambi dengan cara mengolah data heat reat pembangkit menggunakan pendekatan fungsi polynomial, yang kemudian dikalikan dengan fungsi biaya bahan bakar sehingga diperoleh data seperti pada Tabel 4.

Untuk mendapat hasil dari perhitungan karakteristik input-output pembangkit, digunakan nilai head rate (panas) dan energi yang dihasil kan dari masing-masing unit pembangkit thermal.
Tabel 4. Karakteristik Input-Output Pembangkit Sistem Kelistrikan Jambi

\begin{tabular}{|l|c|l|}
\hline \multicolumn{1}{|c|}{ Pembangkit } & Unit & Karakteristik Input-0utput (Btu/Jam) \\
\hline PLTG BATANGHARI & Unit 1 & $\mathrm{H} 1=440.0110+17.226 \mathrm{PT}_{1}+0.2372 \mathrm{PT}_{1}{ }^{2}$ \\
\cline { 2 - 3 } & Unit 2 & $\mathrm{H} 2=561.7875+28.625 \mathrm{PT}_{2}+0.4856 \mathrm{PT}_{2}{ }^{2}$ \\
\hline PLTMG SEI GELAM & Unit 3 & $\mathrm{H} 3=1.7262+0.2558 \mathrm{PT}_{3}+0.0191 \mathrm{PT}_{3}{ }^{2}$ \\
\hline PLTMG SEWA & Unit 4 & $\mathrm{H} 4=290.4418+39.7496 \mathrm{PT}_{4}+2.2298 \mathrm{PT}_{4}{ }^{2}$ \\
\cline { 2 - 3 } & Unit 5 & $\mathrm{H} 5=122.5773+3.5542 \mathrm{PT}_{5}+0.0720 \mathrm{PT}_{5}{ }^{2}$ \\
\hline PLTG SEWA & Unit 6 & $\mathrm{H} 6=3.3565+0.0568 \mathrm{PT}_{6}+0.002372 \mathrm{PT}_{6}{ }^{2}$ \\
\hline
\end{tabular}

\subsubsection{Karakteristik Persamaan Biaya Bahan Bakar Pembangkit Sistem Kelistrikan Jambi \\ Karakteristik ini diperoleh dari} mengalikan karakteristik input output dengan bahan bakarnya.

Tabel 5. Karakteristik Persamaan Biaya Bahan Bakar Pembangkit Sistem Kelistrikan Jambi

\begin{tabular}{|l|c|l|}
\hline \multicolumn{1}{|c|}{ Pembangkit } & Unit & \multicolumn{1}{|c|}{$\begin{array}{c}\text { Karakteristik Persamaan Biava bahan } \\
\text { Bakar (Rp/Jam) }\end{array}$} \\
\hline PLTG BATANGHARI & Unit 1 & $\mathrm{~F} 1=2200055+86130 \mathrm{PT}_{1}+1186 \mathrm{PT}_{1}{ }^{2}$ \\
\cline { 2 - 3 } & Unit 2 & $\mathrm{F} 2=2808938+143125 \mathrm{PT}_{2}+2428 \mathrm{PT}_{2}{ }^{2}$ \\
\hline PLTMG SEI GELAM & Unit 3 & $\mathrm{F} 3=8631+1279 \mathrm{PT}_{3}+95.5 \mathrm{PT}_{3}{ }^{2}$ \\
\hline PLTMG SEWA & Unit 4 & $\mathrm{F} 4=1452209+198748 \mathrm{PT}_{4}+11149 \mathrm{PT}_{4}{ }^{2}$ \\
\cline { 2 - 3 } & Unit 5 & $\mathrm{F} 5=612886.5+17771 \mathrm{PT}_{5}+360 \mathrm{PT}_{5}{ }^{2}$ \\
\hline PLTG SEWA & Unit 6 & $\mathrm{F} 6=16782.5+284 \mathrm{PT}_{6}+11.86 \mathrm{PT}_{6}{ }^{2}$ \\
\hline
\end{tabular}

\subsubsection{Karakteristik Laju Pertambahan Biaya Bahan Bakar Pembangkit Sistem Kelistrikan Jambi}

Karakteristik ini diperoleh dengan cara mengalikan turunan pertama karakteristik inputoutput dengan harga bahan bakarnya. Tabel 6 merupakan tabel karakteristik laju pertambahan biaya bahan bakar PLTG dan PLTMG di Jambi.

Tabel 6. Karakteristik Laju Pertambahan Biaya Bahan Bakar Pembangkit Sistem Kelistrikan Jambi

\begin{tabular}{|l|c|l|}
\hline \multicolumn{1}{|c|}{ Pembangkit } & Unit & $\begin{array}{c}\text { Karakteristik Laju Pertambahan Biava } \\
\text { bahan Bakar (Rp/kwh) }\end{array}$ \\
\hline PLTG BATANGHARI & Unit 1 & $\mathrm{F} 1=86130+2372 \mathrm{PT}_{1}$ \\
\cline { 2 - 3 } & Unit 2 & $\mathrm{F} 2=143125+4856 \mathrm{PT}_{2}$ \\
\hline PLTMG SEI GELAM & Unit 3 & $\mathrm{F} 3=1279+191 \mathrm{PT}_{3}$ \\
\hline PLTMG SEWA & Unit 4 & $\mathrm{F} 4=198748+22298 \mathrm{PT}_{4}$ \\
\cline { 2 - 3 } & Unit 5 & $\mathrm{F} 5=17771+720 \mathrm{PT}_{5}$ \\
\hline PLTG SEWA & Unit 6 & $\mathrm{F} 6=284+23.72 \mathrm{PT}_{6}$ \\
\hline
\end{tabular}




\subsubsection{Urutan Prioritas Unit Baiya Bahan Bakar Pembangkit Sistem Kelistrikan Jambi \\ Dari perhitungan laju pertambahan biaya} bahan bakar diatas, maka dapat diperoleh urutan prioritas pembangkit yang dioperasikan duluan. Pembangkit yang dioperasikan terlebih dahulu yaitu pembangkit yang biaya per-kwh paling murah yaitu dengan cara mengalikan masingmasing persamaan laju pertambahan biaya bahan bakar dari unit-unit pembangkit dengan daya maksimalnya. Urutan prioritas dapat dilihat pada Tabel 7.

Tabel 7. Urutan Prioritas

\begin{tabular}{|c|l|c|c|}
\hline No & \multicolumn{1}{|c|}{ Pembangkit } & Unit & Biaya Bahan Bakar (Rp/kwh) \\
\hline 1 & PLTG Batanghari 1 & Unit 1 & $1.549,18$ \\
\hline 2 & PLTMG sei gelam & Unit 3 & $1.655,9$ \\
\hline 3 & PLTG Sewa & Unit 6 & $2.374,84$ \\
\hline 4 & PLTG Batanghari 2 & Unit 2 & $2.839,49$ \\
\hline 5 & PLTMG sewa & Unit 5 & $3.937,1$ \\
\hline 6 & PLTMG Sewa & Unit 4 & $4.663,24$ \\
\hline
\end{tabular}

\subsubsection{Penjadwalan Unit Pembangkit Sistem Kelistrikan Jambi dengan Metode Daftar Prioritas \\ Penjadwalan dilakukan dalam waktu 1} hari (24 jam) yaitu sampel pada tanggal 20 november 2015. Contoh perhitungan dilakukan untuk beban dasar $139 \mathrm{MW}$, beban menengah 146 MW, dan beban puncak sebesar 235 MW.

Setelah diketahui besarnya daya listrik yang harus dibangkitkan oleh pembangkit thermal, selanjutnya dimasukkan kepersamaan $2^{\mathrm{n}}-1$ kombinasi unit pemangkit dimana $\mathrm{n}=$ jumlah unit pembangkit. Dengan $\mathrm{n}=6$ unit pembangkit jadi $2^{\mathrm{n}}-1=2^{6}-1=63$ kombinasi. Kemudian kombinasi on/off unit pembangkit yang akan digunakan dalam penjadwalan adalah dapat dilihat pada Tabel 8 .

Tabel 8. Kombinasi On/Off Unit Pembangkit yang di periksa

\begin{tabular}{|c|c|c|c|c|c|c|c|}
\hline \multirow{2}{*}{ NO } & \multicolumn{7}{|c|}{ UNIT PEMBANGKIT } \\
\cline { 2 - 8 } & Unit 1 & Unit 2 & Unit 3 & Unit 4 & Unit 5 & Unit 6 & Pmax (MW) \\
\hline 8 & 0 & 0 & 1 & 0 & 0 & 0 & 80 \\
\hline 12 & 0 & 0 & 1 & 1 & 0 & 0 & 92 \\
\hline 24 & 0 & 1 & 1 & 0 & 0 & 0 & 109 \\
\hline 46 & 1 & 0 & 1 & 1 & 1 & 0 & 151 \\
\hline 56 & 1 & 0 & 1 & 0 & 1 & 0 & 139 \\
\hline 57 & 1 & 1 & 1 & 0 & 0 & 1 & 238 \\
\hline 61 & 1 & 1 & 1 & 1 & 0 & 1 & 250 \\
\hline
\end{tabular}

Berdasarkan persamaan kenaikan biaya bahan bakar dan batas kapasitasmaksimum dan minimum dari generator untuk kombinasi on/off unit pembangkit yang diperiksa yaitu kombinasi 57 untuk melayani beban puncak sekitar jam 18.00-22.00 wib.

Untuk daftar prioritas 5 unit dengan $\mathrm{P}_{\mathrm{D}}=$ 235 MW, pembangkit yang bekerja dengan urutan prioritas adalah :

1. PLTG Batanghari Unit 1

2. PLTMG Sei Gelam unit 3

3. PLTMG Sewa Unit 6.

4. PLTG Batanghari Unit 2

Penjadwalan dengan menggunakan daftar prioritas data yang dibutuhkan yaitu karakteristik persamaan biaya bahan bakar (Rp/jam) dari masing-masing pembangkit thermal, daya yang dibutuhkan sistem $\left(\mathrm{P}_{\mathrm{D}}\right)$ serta kapasitas maksimum dan minimum tiap unit. Pembahasan Contoh perhitungan untuk metode daftar prioritas dengan $\mathrm{P}_{\mathrm{D}}=235 \mathrm{MW}$. Pembangkit yang bekerja menurut daftar prioritas adalah:

1. PLTG Batanghari Unit 1

2. PLTMG Sei Gelam unit 3

3. PLTMG Sewa Unit 6.

4. PLTG Batanghari Unit 2

Maka dapat dihitung pembangian beban sebagai berikut:

Karakteristik input output pembangkit termal dan daya mampu minimum serta daya mampu maksimum pembangkit (lihat Tabel 4).

$\mathrm{H} 1=440.0110+17.226 \mathrm{PT}_{1}+0.2372 \mathrm{PT}_{1}{ }^{2}$

$\mathrm{H} 3=1.7262+0.2558 \mathrm{PT}_{3}+0.0191 \mathrm{PT}_{3}^{2}$

$\mathrm{H} 6=3.3565+0.0568 \mathrm{PT}_{6}+0.002372 \mathrm{PT}_{6}{ }^{2}$

$\mathrm{H} 2=561.7875+28.625 \mathrm{PT}_{2}+0.4856 \mathrm{PT}_{2}{ }^{2}$

Dengan Batas- batas generator:

$26 \leq \mathrm{PT}_{1} \leq 29 \mathrm{MW}$

$60 \leq \mathrm{PT}_{3} \leq 80 \mathrm{MW}$

$66 \leq \mathrm{PT}_{6} \leq 100 \mathrm{MW}$

$26 \leq \mathrm{PT}_{2} \leq 29 \mathrm{MW}$

Maka dapat dihitung pembagian pembebanan dengan menggunakan daftar prioritas kemudian hitung output masingmasing unit $\mathrm{P}_{1}, \mathrm{P}_{3}, \mathrm{P}_{6}, \mathrm{P}_{2}$. Dengan $\mathrm{P}_{\mathrm{D}}=235 \mathrm{MW}$ maka didapat :

Diset sesuai dengan daya maksimum nya $\mathrm{P}_{1}=29 \mathrm{MW}, \mathrm{P}_{3}=80 \mathrm{MW}, \mathrm{P}_{6}=97 \mathrm{MW}, \mathrm{P}_{2}=29$ 
MW. Kemudian menggunakan fungsi kenaikan biaya bahan bakar untuk menentukan total biaya pembangkitan perjam (lihat Tabel 5).

Jam $18.00-22.00 \mathrm{wib}$, dengan $\mathrm{P}_{\mathrm{D}}=235 \mathrm{MW}$

$\mathrm{P}_{1}=29 \mathrm{MW}$,

$\mathrm{P}_{3}=80 \mathrm{MW}$,

$\mathrm{P}_{6}=97 \mathrm{MW}$,

$\mathrm{P}_{2}=29 \mathrm{MW}$

$$
\begin{aligned}
\mathrm{P} 1 & =2200055+86130 \mathrm{PT}_{1}+1186 \mathrm{PT}_{1}{ }^{2} \\
& =2200055+86130(29)+1186(29)^{2} \\
& =569.525,1 \quad \mathrm{Rp} / \mathrm{Jam} \\
\mathrm{P} 3 & =8631+1279 \mathrm{PT}_{3}+95.5 \mathrm{PT}_{3}{ }^{2} \\
& =8631+1279(80)+95.5(80)^{2} \\
& =722.151 \quad \mathrm{Rp} / \mathrm{Jam} \\
\mathrm{P} 6 & =16782.5+284 \mathrm{PT}_{6}+11.86 \mathrm{PT}_{6}{ }^{2} \\
& =16782.5+284(100)+11.86(100)^{2} \\
& =163.782,5 \quad \mathrm{Rp} / \mathrm{Jam}^{2} \\
\mathrm{P} 2 & =2808938+143125 \mathrm{PT}_{2}+2428 \mathrm{PT}_{2}{ }^{2} \\
& =2808938+143125 \mathrm{PT}_{2}+2428 \mathrm{PT}_{2}{ }^{2} \\
& =900.151,1 \quad \mathrm{Rp} / \mathrm{Jam}^{2}
\end{aligned}
$$

jadi, total biaya pembangkitan untuk $\mathrm{P}_{\mathrm{D}}=235$ MW adalah :

\begin{tabular}{|c|c|c|c|c|}
\hline \multirow{2}{*}{$\begin{array}{c}\text { Pembangkit } \\
\text { (MT) }\end{array}$} & \multirow{2}{*}{$\begin{array}{c}\text { Daya Mampu } \\
\text { (MIV) }\end{array}$} & \multicolumn{3}{|c|}{ Waktu (h) } \\
\hline & & $06.00-17.00$ & $18.00-22.00$ & $23.00-05.00$ \\
\hline Unit 1 & 29 & 29 & 29 & 29 \\
\hline Unit 2 & 29 & - & 29 & - \\
\hline Unit 3 & 80 & 80 & 80 & 75 \\
\hline Unit 4 & 12 & - & - & 12 \\
\hline Unit 5 & 30 & 30 & - & 30 \\
\hline Unit 6 & 100 & - & 97 & - \\
\hline \multicolumn{2}{|c|}{ Total } & 139 & 235 & 146 \\
\hline
\end{tabular}

$$
\begin{aligned}
\mathbf{P}_{\text {total }}= & \mathrm{P}_{1}+\mathrm{P}_{3}+\mathrm{P}_{6}+\mathrm{P}_{2} \\
= & 569.525,1+722.151+163.782,5+ \\
& 900.151,1 \\
= & 15.582 .695,50 \quad \text { Rp/Jam }
\end{aligned}
$$

Hasil-hasil perhitungan total biaya pembangkit dengan beban yang berbeda menggunakan metode daftar prioritas maka diperoleh daftar seperti pada Tabel 9.

Tabel 9. Hasil Penjadwalan Pembangkit dengan Menggunakan Metode Daftar Prioritas

\begin{tabular}{|c|c|c|c|}
\hline No & Jam & Beban Rembangkit (MW) & Biaya. Rembangkit (Rp) \\
\hline 1 & 00.00 & 146 & $13.475 .725,3$ \\
2 & 01.00 & 146 & $13.475 .725,3$ \\
3 & 02.00 & 146 & $13.475 .725,3$ \\
4 & 03.00 & 146 & $13.475 .725,3$ \\
5 & 04.00 & 146 & $13.475 .725,3$ \\
6 & 05.00 & 146 & $13.475 .725,3$ \\
7 & 06.00 & 139 & $12.931 .461,2$ \\
8 & 07.00 & 139 & $12.931 .461,2$ \\
9 & 08.00 & 139 & $12.931 .461,2$ \\
10 & 09.00 & 139 & $12.931 .461,2$ \\
11 & 10.00 & 139 & $12.931 .461,2$ \\
12 & 11.00 & 139 & $12.931 .461,2$ \\
13 & 12.00 & 139 & $12.931 .461,2$ \\
14 & 13.00 & 139 & $12.931 .461,2$ \\
15 & 14.00 & 139 & $12.931 .461,2$ \\
16 & 15.00 & 139 & $12.931 .461,2$ \\
17 & 16.00 & 139 & $12.931 .461,2$ \\
18 & 17.00 & 139 & $12.931 .461,2$ \\
19 & 18.00 & 235 & $15.582 .695,50$ \\
20 & 19.00 & 235 & $15.582 .695,50$ \\
21 & 20.00 & 235 & $15.582 .695,50$ \\
22 & 21.00 & 235 & $15.582 .695,50$ \\
23 & 22.00 & 235 & $13.475 .725,3$ \\
24 & 23.00 & 146 & $102.864 .238,65$ \\
& & & \\
\hline \multicolumn{2}{|c|}{ Total Biaya. Rembangkitan (Rp) } & \\
\hline
\end{tabular}

Tabel 10. Penjadwalan Membagi Beban di UnitUnit Pembangkit Sistem Kelistrikan Jambi Seltelah Optimasi

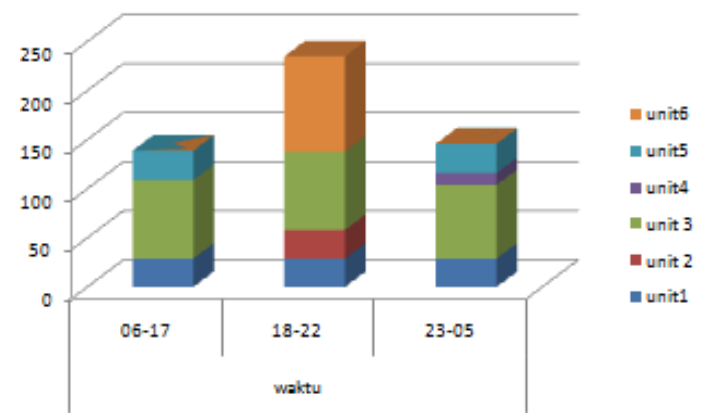

Gambar 4. Grafik penjadwalan membagi bebean di unit-unit pembangkitan sistem kelistrikan jambi setelah optimasi

Dengan menggunakan Metode daftar prioritas, diperoleh hasil penjadwalan unit pembangkit thermal sistem kelistrikan Jambi pada Tabel 5. Hasil perhitungan penjadwalan unit pembangkit ini selanjutnya dibandingkan dengan data riil sistem pada hari Minggu tanggal 20 Nopember 2015. Hasil optimalisasi penjadwalan pembangkit pada sistem kelistrikan Jambi dengan Metode daftar prioritas dalam penyelesaian masalah Unit Commitment didapat biaya bahan bakar sebesar Rp.102.864.238,65 Adapun biaya bahan bakar pembangkit dari penjadwalan PT. PLN (Persero) Wilayah Jambi sebesar Rp.163.755.996,30 sehingga dengan demikian ada penghematan sebesar Rp. 60.891.757,65./bulan

\section{KESIMPULAN}

Setelah dilakukan perhitungan didapat economic dispatch yang digunakan untuk pembagi beban diantara unit-unit pembangkit . pada pukul 06.00-07.00 adalah beban dasar dengan total daya mampu 139 MW pembangkit yang beroperasi adalah unit $1,3,5$. Pada pukul 18.00-22.00 adalah beban puncak dengan total daya mampu 235 MW pembangkit yang 
beroperasi adalah unit 1,2,3,6 . Pada pukul 23.00-05.00 adalah beban menengah dengan total daya $146 \mathrm{MW}$ pembangkit yang beroperasi adalah unit $1,3,4,5$.

Hasil optimalisasi penjadwalan pembangkit pada sistem kelistrikan Jambi dengan Metode daftar prioritas dalam penyelesaian masalah Unit Commitment sebesar Rp.102.864.238,65. Ada pun biaya pembangkit dari penjadwalan PT. PLN (Persero) Wilayah Jambi sebesar Rp.163.755.996,30 sehingga dengan demikian ada penghematan sebesar Rp . 60.891 .757 dalam satu bulan.

\section{DAFTAR PUSTAKA}

[1] Marsudi, Djiteng. (2011). Buku" Pembangkit Energi Listri (Edisi Kedua)'”. Jakarta:Erlangga.

[2] A.J.Wood,B.F Wollenbarg.1996. Buku "Power Generation, Operational, and Contro.second edition", Jhon Wiley and Sons, Inc ,New York.

[3] Marsudi,Djiteng. (2006). Buku "Operasi sistem Tenaga Listrik”..Jakarta:Erlangga

[4] Am. Liyas, Ontoseno Penangsang, Adi Soeprijanto.(2010). Jurnal "Optimasi Economic Dispatch Pembangkit Termal Sistem 500 KV Jawa-Bali menggunakan Modified Improved Particle Swarm Optimization (MPISO)”. Nasional Conference :Design and Application of Tecnology,Teknik Elektro Universitas Kairum Ternate.

[5] Zulfatri Aini.(2012). Jurnal"Analisis Penjadwalan Unit-Unit Pembangkit Listrik Dengan Menggunakan Metode Unit Decommitment”. Vol.13 No.2 Teknik Elektro universitas Islam Negeri Sultan F kasim Riau.

[6] Nizar Rizky R.sarjiya, M. Isnaeni B.S.(2012). Jurnal "Optimasi Penjadwalan Pembangkit Termal Dengan Sistem Penyimpanan Energi Menggunakan Algoritma Genetika”. Penelitian Teknik Elektro dan Teknologi Informasi, Universitas Gadjah Mada Yogyakarta.

[7] Sartika Veronika Angdrie, dkk.(2013). Jurnal "Optimasi Biaya Bahan Bakar untuk Penjadwalan Unit-Unit Pada Pembangkit Thermal Sistem Minahasa Dengan Metode Iterasi
Landa”.,ejournal.unsrat.ac.id/index.php/e lekdankom/article/view/599. Teknik elektro UNSRAT Monado.

[8] Sugeng Riyanto, Hadi Suyono, Mahfudz shidiq.(2013). Jurnal "Penjadwalan Pembangkit Tenaga Listrik Menggunakan ANT Colony optimization",jurnaleec cis.ud.ac.id home vol 6 No 22. Teknik Elektro Universitas Brawijaya Malang.

[9] Dheo Kristianto,dkk.(2013). Jurnal "Operasi Ekomonis Pembangkit Tenaga Listrik Dengan Metode Iterasi Lambda Menggunakan Komputasi Pararel" ,www.e-jurnal.com/IV.html. Teknik Elektro Universitas Brawijaya Malang..

[10] Riva Nihayatul marifah, yadi Mulyadi, Ade Gafar Abdullah.2013.Jurnal "Operasi Ekonomis Pembangkit Termal Sistem 500 KV Jawa-Bali dengan Pendekatan Algoritma Fuzzy Logic”. Electrons, vol 12. No2, 127138. Bandung.

[11] Yulianto Mariang, L.S patras,ST,MT, M.Tuegeh, ST,MT, Ir.H Turmaliang, MT.(2013). Jurnal "Optimalisasi Penjadwalan Pembangkit Listrik Sistem Sorong ",ejurnal.unsrat.ac.id/index.php/el ek\&kom/article/view/609. Teknik Elektro UNSRAT Manado.

[12] R.M. Mangawa, L.S. Patras, M. Tuegeh, F. Lisi. (2013). Jurnal "Koordinasi Pembangkit Hidro-Termal di Sistem Sulawesi Selatan dan Sulawesi Barat", portalgaruda.org/article.php $=109$ 229\&val=1028. Teknik Elektro UNSRAT Manado.

[13] Fityan Thalib, Tripratiwi Handayani, dan Sabhan Kanata. (2014) . Jurnal "Optimasi Pembangkit Ekonomis Pada Unit-Unit Pembangkit Listrik Tenaga Diesel Telaga Menggunakan Modifikasi Particle Swarm Optimization (MPSO)”. Electrichsan ISSN : 2252 - 8237. Vol. 1. N0. 1. Teknik Elektro Universitas Ichsan Gorontalo.

[14] Cekdin, Cekmas.(2010) . Buku "Sistem Tenaga Listrik Contoh Soal Dan Penyelesaiannya Menggunakan Matlab”. Yogyakarta.

\section{Biodata Penulis}

Delima, lahir di Nipah- panjang pada tahun 1981. Magister Teknik Elektro Universitas Andalas Padang. 